\title{
The visual function assessment: from birth to the follow up
}

\author{
Daniela Ricci ${ }^{1,2^{*}}$, Domenico M Romeo ${ }^{1}$, Eugenio Mercuri ${ }^{1}$ \\ From XXI Congress of the Italian Society of Neonatology \\ Palermo, Italy. 24-26 September 2015
}

\section{Background}

Preterm infants have a high risk to develop visual deficits due to retinopathy of prematurity (ROP), brain lesionsand prematurity per se [1]. The possibility to assess different aspects of visual function can allow early and specific intervention in an attempt to reduce the risk of difficulties in motor coordination, attention and learning at school age.

The aim is to identify early signs of visual and motorperceptual deficit in the first years in order to program a specific intervention before school age.

\section{Methods}

Verypreterm infants born at Gestational Age (GA) $<31$ weeks, with and without brain lesions and ROP $\leq$ stage 2 , were assessed at 35 and 40 weeks post-menstrual age using a visual assessment specifically designed for neonates; a structured follow up assessment, including fixing, tracking, visual acuity, visual fields and visual attention (using the Fixation Shift test) was used at 3, 5 and 12 months corrected age. Tractography of the optical radiation was performed in some consecutive infants in the neonatal period. Results at all the tests were compared with normative data on term born infants.

\section{Results}

Ocular movements and tracking were more complete in preterm infants at 35 weeks than in full term infants, whereas reaction to a colored target, discrimination of stripes and attention at distance were more mature at term age both in preterm and term born infants. Tractography of the optical radiation showed that at term equivalent age visual assessment was significantly correlated with fractional anisotropy values $(P<0.001)$. At 3,5

\footnotetext{
* Correspondence: dricciola@gmail.com

${ }^{1}$ Pediatric Neurology Unit, Catholic University, Rome, Italy

Full list of author information is available at the end of the article
}

and 12 months preterm infants showed similar results to term born infants in all visual aspects but visual attention, with a high percentage of infants failing or refusing the test. Irrespective from the MRI findings, preterm infants with a normal neonatal assessment showed normal visual competences at 12 months corrected age.

\section{Conclusions}

A structured visual assessment can be reliablesince the neonatal age [2]. Some visual aspects are influenced by extrauter ineexperience, others depend on cortical maturation [3] as proved by the level of development of the white matter in the optical radiation [4]. The neonatal assessment has a good correlation with visual development at one year [5]. In low-risk preterms visual attention appears to be already impaired in the first year from birth [6].

\section{Authors' details}

${ }^{1}$ Pediatric Neurology Unit, Catholic University, Rome, Italy. ${ }^{2}$ National Center for Services and Research for the Prevention of Blindness and Rehabilitation of the Visually Impaired - IAPB Italia onlus, Italy.

\section{Published: 24 September 2015}

References

1. Fielder $\mathrm{A}$, Blencowe $\mathrm{H}, \mathrm{O}^{\prime}$ Connor A, Gilbert C: Impact of retinopathy of prematurity on ocular structures and visual functions. Arch Dis Child Fetal Neonatal Ed 2015, 100:F 179-184.

2. Ricci D, Romeo DMM, Serrao F, Cesarini L, Gallini F, Cota F, Zuppa A, Romagnoli C, Cowan F, Mercuri E: Application of a neonatal assessment of visual function in a population of low risk full-term newborn. Early Hum Dev 2008, 84:277-280.

3. Ricci D, Cesarini L, Romeo DM, Gallini F, Serrao F, Groppo M, De Carli A, Cota F, Lepore D, Molle F, Ratiglia R, De Carolis MP, Mosca F, Romagnoli C, Guzzetta F, Cowan F, Ramenghi LA, Mercuri E: Visual function at 35 and 40 weeks' postmenstrual age in low-risk preterm infants. Pediatrics 2008, 122:e 1193-1198.

4. Bassi L, Ricci D, Volzone A, Allsop JM, Srinivasan L, Pai A, Ribes C, Ramenghi LA, Mercuri E, Mosca F, Edwards AD, Cowan FM, Rutherford MA, Counsell SJ: Probabilistic diffusion tractography of the optic radiations 
and visual function in preterm infants at term equivalent age. Brain 2008, 131:573-582.

5. Ricci D, Romeo DM, Gallini F, Groppo M, Cesarini L, Pisoni S, Serrao F, Papacci P, Contaldo I, Perrino F, Brogna C, Bianco F, Baranello G, Sacco A, Ometto A, Cilauro S, Mosca F, Romagnoli C, Romeo MG, Cowan F, Cioni G Ramenghi LA, Mercuri E: Early visual assessment in preterm infants with and without brain lesions: correlation with visual and neurodevelopmental outcome at 12 months. Early Hum Dev 2011, 87:177-182.

6. Ricci D, Cesarini L, Gallini F, Serrao F, Leone D, Baranello G, Cota F, Pane M, Brogna C, De Rose P, Vasco G, Alfieri P, Staccioli S, Romeo DM, Tinelli F, Molle F, Lepore D, Baldascino A, Ramenghi LA, Torrioli MG, Romagnoli C, Cowan F, Atkinson J, Cioni G, Mercuri E: Cortical visual function in preterm infants in the first year. J Pediatr 2010, 156:550-555.

doi:10.1186/1824-7288-41-S1-A34

Cite this article as: Ricci et al:: The visual function assessment: from birth to the follow up. Italian Journal of Pediatrics 2015 41(Suppl 1):A34.

\section{Submit your next manuscript to BioMed Central} and take full advantage of:

- Convenient online submission

- Thorough peer review

- No space constraints or color figure charges

- Immediate publication on acceptance

- Inclusion in PubMed, CAS, Scopus and Google Scholar

- Research which is freely available for redistribution

Submit your manuscript at www.biomedcentral.com/submit 